\title{
Candida cabralensis sp. nov., a yeast species isolated from traditional Spanish blue-veined Cabrales cheese
}

\author{
Ana Belén Flórez, ${ }^{1}$ Carmela Belloch, ${ }^{2}$ Pablo Álvarez-Martín, ${ }^{1}$ \\ Amparo Querol ${ }^{2}$ and Baltasar Mayo ${ }^{1}$ \\ ${ }^{1}$ Departamento de Microbiología y Bioquímica, Instituto de Productos Lácteos de Asturias, CSIC, \\ Carretera de Infiesto s/n, 33300-Villaviciosa, Asturias, Spain \\ ${ }^{2}$ Departamento de Biotecnología, Instituto de Agroquímica y Tecnología de Alimentos, CSIC, \\ 46100-Burjassot, Valencia, Spain
}

Correspondence

Baltasar Mayo

baltasar.mayo@ipla.csic.es

\begin{abstract}
Three yeast strains, $1 A D 8^{\top}, 3 A D 15$ and $3 A D 23$, belonging to a previously unknown yeast species were isolated from two independent batches of the Spanish blue-veined Cabrales cheese, a traditional cheese manufactured without the addition of starter and mould cultures. Physiological characterization revealed that the unknown yeast is not fermentative and does not assimilate lactose; rather it assimilates DL-lactic acid and ethanol, major end products of lactic acid bacteria metabolism in cheese. The novel yeast is anamorphic. Phylogenetic tree reconstruction based on nucleotide sequence comparison of the D1/D2 region of the 26S rRNA gene showed that Pichia terricola and Pichia fermentans are the closest relatives of the unknown species. The name Candida cabralensis sp. nov. is proposed, and the isolate $1 \mathrm{AD}^{\top}\left(=\mathrm{CECT} 13027^{\top}=\mathrm{CBS}\right.$ $\left.11679^{\top}\right)$ is the type strain of this novel taxon.
\end{abstract}

Yeasts are common contaminants of milk and dairy products and contribute to food spoilage and even food poisoning (Pitt \& Hocking, 1997). However, specific yeast species are essential for the typical characteristics of certain products, such as fermented milks (kefir, koumis, viili and longfil) and cheeses of the Brie and Camembert varieties (Roostita \& Fleet, 1996; Gripon, 1999). They are also major constituents of the microbiota of many other types of cheese, including blue-veined varieties (Beresford et al., 2001; Wouters et al., 2002). Yeasts can interact with starter and non-starter lactic acid bacteria components and also with Penicillium roqueforti strains, promoting or inhibiting their growth (Addis et al., 2001; Gadaga et al., 2001). In addition, utilization of lactic acid by yeasts during ripening contributes to curd deacidification, which allows growth of secondary floras in cheese (Ferreira \& Viljoen, 2003). Yeasts may also have a direct role in the final organoleptical and rheological properties of cheeses through their proteolytic and lipolytic activities (Bockelmann, 1999; Ferreira \& Viljoen, 2003).

Cabrales is the most famous of the traditional Spanish blue-veined cheeses and was awarded with a Protection of Designation of Origin (PDO) label in 1989. Traditional manufacture of Cabrales cheese involves curdling

The GenBank/EMBL/DDBJ accession numbers for the D1/D2 26S rRNA gene sequences of strains 1AD8, 3AD15 and 3AD23 are FJ755462, FJ755463 and FJ755464, respectively. mixtures of evening and morning milks at $28-30{ }^{\circ} \mathrm{C}$ with a farm-made kid rennet extract, and neither starter cultures nor $P$. roqueforti spores are added to the milk (Flórez et al., 2006). Acidification and ripening relies on growth and activity of indigenous micro-organisms from the milk, the rennet extract and the manufacturing and ripening environments. After a short period of drying, maturation takes place in natural caves within the area of manufacture at a nearly constant temperature (ranging from 9 to $12{ }^{\circ} \mathrm{C}$ ) and humidity (approx. $95 \%$ ). Under these conditions, $P$. roqueforti develops into the cheese matrix, providing the final product with its unique appearance and sensory characteristics. Though moderate to large differences in counts of total and indicator microbial populations are observed between batches, Cabrales is a complex microbial habitat in which many types of bacteria, yeasts and moulds interact and evolve throughout the manufacturing and ripening processes (Flórez et al., 2006).

The microbiota of Cabrales cheese was recently investigated for the presence of yeasts. Seventy-four yeast strains were isolated and identified (Álvarez-Martín et al., 2007). Physiological characterization and restriction fragment length polymorphism of the ITS1-5.8S-ITS2 rDNA region indicated that three yeast isolates, $1 \mathrm{AD} 8^{\mathrm{T}}, 3 \mathrm{AD} 15$ and 3AD23, showed similar patterns to those of Pichia fermentans or Pichia membranaefaciens, although the isolates could not be unequivocally identified. 
In this study, the complete phenotypic characterization of strains $1 \mathrm{AD} 8,3 \mathrm{AD} 15$ and $3 \mathrm{AD} 23$ was undertaken, and a phylogenetic analysis based on the sequences of the D1/D2 domains of the 26S rRNA gene and the ITS1-5.8S-ITS2 rDNA region was performed. According to previous phylogenetic studies (Kurtzman et al., 2008), the 26S rRNA gene sequences of the novel yeast isolates corresponded to a novel species in the Pichia clade. The name Candida cabralensis sp. nov. is proposed to accommodate these three strains isolated from Cabrales cheese.

\section{Yeast isolation and physiological characterization}

The three unidentified yeasts were isolated from two batches of Cabrales cheese sampled in November 2002 (strain $1 \mathrm{AD} 8^{\mathrm{T}}$ ) and March 2003 (strains 3AD15 and 3AD23) in Tielve, a province of Asturias, Spain. Details of sample processing and isolation of yeasts were described by Álvarez-Martín et al. (2007).

Yeast morphology was examined after incubation on malt extract agar (MEA) for three days at $25{ }^{\circ} \mathrm{C}$. Asci and ascospore production was tested by growing the isolates for up to one month at $25{ }^{\circ} \mathrm{C}$ on yeast morphology agar, acetate agar, cornmeal agar (CMA), Gorodkowa agar and $5 \%$ MEA (Yarrow, 1998). The ability to mate was tested by mixing equal amounts of young actively growing cells of the three isolates on the surface of sporulation media incubated at $15{ }^{\circ} \mathrm{C}$ and $30{ }^{\circ} \mathrm{C}$. The plates were microscopically examined for up to 12 weeks. Morphology of the yeast cells was studied using a light microscope (Nikon, Eclipse 90i) (Fig. 1). Mycelium production was tested on CMA after seven and 14 days of growth. Physiological characterization of the strains was performed according to standard methods (Yarrow, 1998). In short, sugar assimilation tests were carried out on agar plates except for that

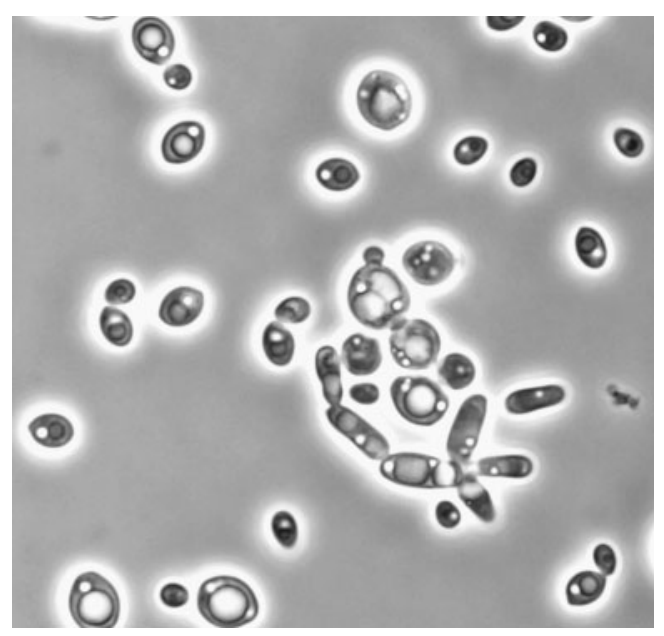

Fig. 1. Budding cells of Candida cabralensis sp. nov. $1 \mathrm{AD}^{\top}{ }^{\top}$ grown on $\mathrm{ME}$ broth for 3 days at $25^{\circ} \mathrm{C}$ and 200 r.p.m. The image was taken with a digital Nikon Act- $2 \mathrm{U}$ camera under phase-contrast mode. of hexadecane, which was assayed in liquid medium. Assimilation of nitrogen compounds was analysed in liquid medium; doubtful and false-positive results were avoided by repeated inoculation of fresh tubes.

\section{Sequencing and phylogenetic analysis}

Yeast cells picked from colonies grown for $48 \mathrm{~h}$ were directly used for PCR as reported previously (EsteveZarzoso et al., 1999). The D1 and D2 domains of the 26S rRNA gene and the ITS1-5.8S-ITS2 rDNA regions were amplified by using the primer pairs NL1 and NL4, and ITS1 and ITS4, respectively (Kurtzman \& Robnett, 2007). PCR amplification and sequencing followed the procedures of Belloch et al. (2007). Sequences were edited and assembled using MEGA version 4 (Kumar et al., 2004) and blasted against the GenBank database to retrieve sequences of the closest relatives. The sequences were included in a multiple alignment and phylogenetic trees were inferred by using the neighbour-joining method (Saitou \& Nei, 1987). Sequence U40085 representing the D1/D2 26S rRNA gene from Schizosaccharomyces pombe was used as the outgroup (Kurtzman \& Robnett, 1998).

\section{Species delineation}

The three strains, $1 \mathrm{AD} 8^{\mathrm{T}}, 3 \mathrm{AD} 15$ and $3 \mathrm{AD} 23$, display identical D1/D2 26S rRNA gene sequences. Phylogenetic analysis based on these D1/D2 26S rRNA gene sequences (Fig. 2) indicated that the novel yeast isolates represent a novel species in the newly proposed Pichia clade (Kurtzman et al., 2008). The novel species Candida cabralensis occupies an isolated position, with Pichia terricola (formerly Issatchenkia terricola) and P. fermentans constituting its group of relatives. Strain 1AD8 (type of the new species) differs from P. fermentans NRRL Y $-1619^{\mathrm{T}}$ and P. terricola NRRL YB- $4310^{\mathrm{T}}$ by 73 and $62 \mathrm{nt}$ substitutions in the D1/D2 region, respectively. The position of these three species within the Pichia clade is unclear because of the low bootstrap value (68\%) (Kurtzman et al., 2008). Furthermore, phylogenetic reconstructions based on multigene sequence analysis did not resolve the position of $P$. fermentans and $P$. terricola within the Pichia clade (Kurtzman et al., 2008). In the case of this group of species, the bootstrap value may increase with the isolation of more strains in the vicinity.

Sequence data and phylogenetic analysis of the ITS1-5.8SITS2 rDNA region confirmed the position of C. cabralensis as a novel species in the proximity of $P$. fermentans and $P$. terricola. One nucleotide difference in the sequence of the ITS1-5.8S-ITS2 rDNA region was found between the three C. cabralensis isolates. BLAST analysis of the ITS1-5.8S-ITS2 rDNA sequence of strain 1AD8 found the closest relatives among isolates of the species $P$. terricola (ranging from 39 to $44 \mathrm{nt}$ differences), whereas the strains representing $P$. fermentans constituted a separate group (nucleotide differences from C. cabralensis ranging from 104 to 109). 


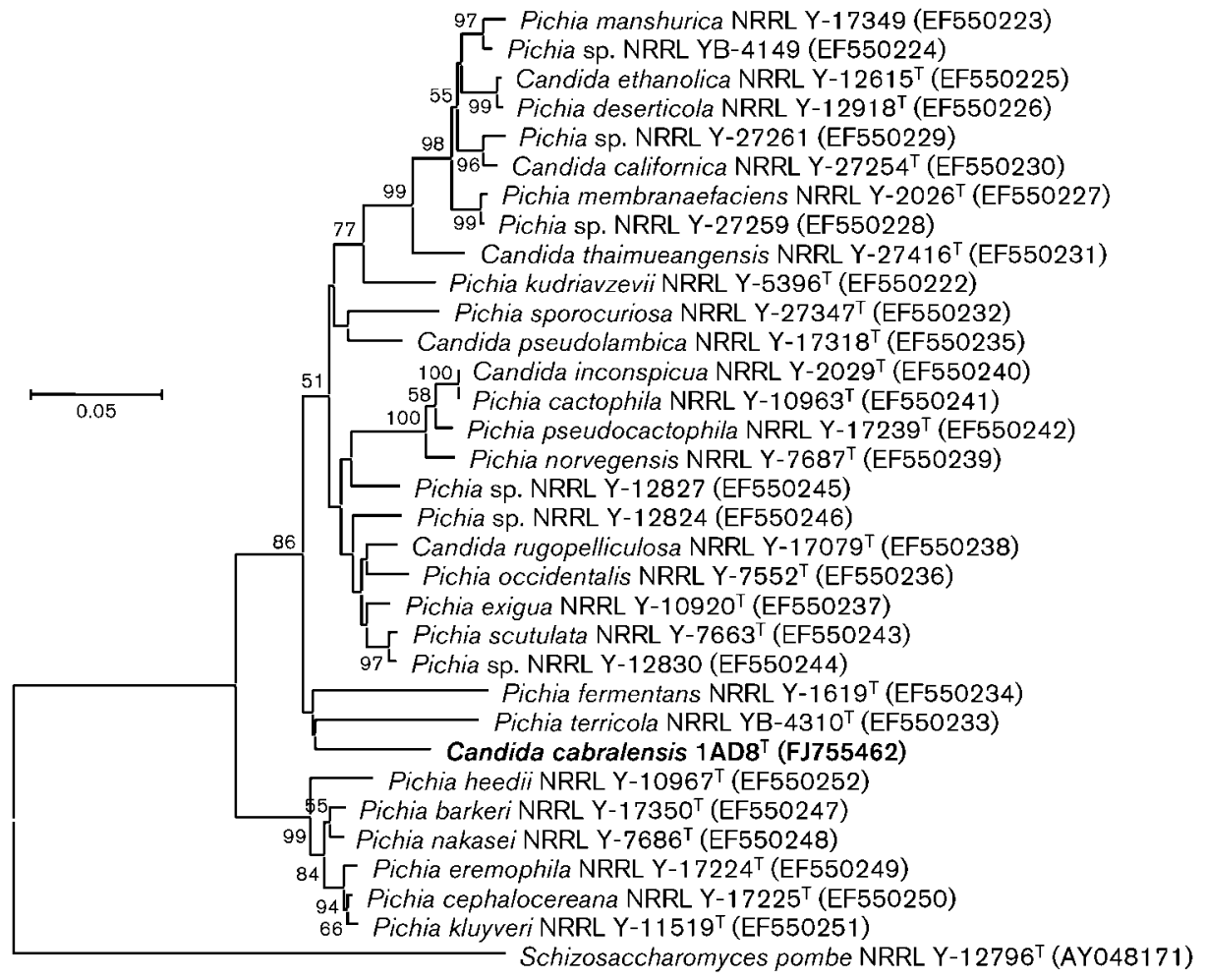

Fig. 2. Unrooted tree showing the phylogenetic relationships of type strains of neighbouring yeast species, orphan yeast strains and Candida cabralensis sp. nov. $1 \mathrm{AD}^{\top}$ based on the sequences of the D1 and D2 domains of the 26S rRNA gene. The sequence of the D1/D2 region from Schizosaccharomyces pombe NRRL Y-12796 ${ }^{\top}$ was used as an outgroup. Accession numbers are shown in parentheses. Bar, percentage of nucleotide substitutions.

Physiologically, C. cabralensis sp. nov. can be clearly distinguished from its relatives by negative fermentation and positive assimilation of raffinose, inulin and melezitose. Assimilation of lactic acid and other end products from the metabolism of lactic acid bacteria (Axelsson, 2004) argues for a tentative role of $C$. cabralensis in the ripening of Cabrales cheese.

\section{Latin diagnosis of Candida cabralensis Flórez, Belloch, Álvarez-Martín, Querol et Mayo sp. nov.}

In medio liquido (ME) post dies 3 ad $25{ }^{\circ} \mathrm{C}$ cellulae ovoideae aut ellipsoideae, $(2-5 \times 3-6 \mu \mathrm{m})$, singulae vel breviter catenatae, per germinationem multipolarem reproducentes. Cultura in agaro malti (MA) post dies $5\left(25^{\circ} \mathrm{C}\right)$ convexa, butyrosa, candida, glabra. In agaro farinae Zea mays (CMA) post dies 14 pseudomycelium sparsum formantur. Ascosporae non fiunt. Fermentatio nulla. Glucosum, sucrosum, melezitosum (exigue), raffinosum, inulinum, glycerolum, ribitolum (exigue), ethanolum, acidum DL-lacticum et acidum succinicum assimilantur at non D-galactosum, L-sorbosum, cellobiosum, lactosum, maltosum, melibiosum, trehalosum, amylum solubile, D-arabinosum, L-arabinosum, D-ribosum, L-rhamnosum, D-xylosum, erythritolum, galactitolum, glucitolum, inositolum, D-mannitolum, methanolum, acidum citricum, acidum D-gluconicum, methyl $\alpha$-D-glucosidum, salicinum, Dglucosaminum hydrochlorium, N-acetyl-D-glucosaminum, hexadecanum, saccharatum, D-glucuronatum, xylitolum nec L-arabinitolum. Lysinum, glucosaminum et ethylaminum hydrochoricum assimilantur, at non kalium nitricum, natrium nitrosum, creatininum, creatinum, imidazolum. Ureum non hydrolysatur. Materia amyloidea iodophila non formantur. Non crescit in $1 \%$ acidum aceticum nec $50 \%$ glucosum. Sine vitaminis externis supplementis crescens. Crescere potest in temperatura $30{ }^{\circ} \mathrm{C}$ at non in $37{ }^{\circ} \mathrm{C}$.

Typus: $1 \mathrm{AD}^{\mathrm{T}}\left(=\mathrm{CECT} 13027^{\mathrm{T}}=\mathrm{CBS} 11679^{\mathrm{T}}\right)$, ex Cabrales caseus isolata. Holotypus lyophilus conservatur in collectiones culturarum Colección Española de Cultivos Tipo (CECT) (Valentia, Hispania) et Centraalbureau voor Schimmelcultures (CSB) (Traiectum, Germaniae).

\section{Description of Candida cabralensis Flórez, Belloch, Álvarez-Martín, Querol and Mayo sp. nov.}

Candida cabralensis (ca.bra.len'sis. N.L. adj. cabralensis from Cabrales, the geographical area where the traditional Cabrales cheese is produced).

After three days at $25{ }^{\circ} \mathrm{C}$ on ME broth, cells are ovoid to ellipsoid $(2-5 \times 3-6 \mu \mathrm{m}$ in size $)$. Cells occur singly or with 
one or two attached multilateral buds and in short chains. Asexual reproduction occurs by multilateral budding. After five days at $25{ }^{\circ} \mathrm{C}$ on MEA, colonies are convex, butyrous, white and smooth. After one to two weeks of growth at $25{ }^{\circ} \mathrm{C}$ on CMA, pseudohyphae are absent or only sparse rudimentary pseudohyphae occur. Sexual reproduction is negative. Fermentation is negative. Assimilates D-glucose, sucrose, melezitose (weakly), raffinose, inulin, glycerol, ribitol (weakly), ethanol, DL-lactic acid and succinic acid, but not D-galactose, L-sorbose, cellobiose, lactose, maltose, melibiose, trehalose, soluble starch, D- or L-arabinose, Dribose, L-rhamnose, D-xylose, meso-erythritol, galactitol, Dsorbitol, myo-inositol, D-mannitol, methanol, citric acid, D-gluconic acid, methyl $\alpha$-D-glucoside, salicin, D-glucosamine hydrochloride, $\mathrm{N}$-actetyl-D-glucosamine, hexadecane, saccharate, D-glucuronate, xylitol or L-arabinitol. Splitting of arbutin is negative. L-Lysine, glucosamine and ethylamine hydrochloride are utilized as nitrogen sources, but not nitrate, nitrite, creatinine, creatine or imidazole. Urea is not hydrolysed. No extracellular starch is produced. No growth is observed in the presence of $1 \%$ acetic acid or $50 \%$ glucose. Growth in vitamin-free medium is positive. No growth is observed at $37{ }^{\circ} \mathrm{C}$.

The type strain, $1 \mathrm{AD} 8^{\mathrm{T}}\left(=\mathrm{CECT} 13027^{\mathrm{T}}=\mathrm{CBS} 11679^{\mathrm{T}}\right)$, isolated from Cabrales cheese, has been deposited in the Spanish Type Culture Collection (Valencia, Spain) and the Centraalbureau voor Schimmelcultures (CSB) (Utrecht, The Netherlands).

\section{Acknowledgements}

This work was supported by research projects to B. M. from the Spanish Ministry of Research and Innovation (MICINN; ref. AGL2007-68961ALI) and 'Instituto Nacional de Investigación y Tecnología Agraria y Agroalimentaria' (INIA; ref. RM2006-00003-00-00). C. B. thanks MICINN and CSIC for an I3P postdoctoral contract, and financial support from an INIA project (ref. RM2007-00010-00-00).

\section{References}

Addis, E., Fleet, G. H., Cox, J. M., Kolak, D. \& Leung, T. (2001). The growth, properties and interactions of yeasts and bacteria associated with the maturation of Camembert and blue-veined cheeses. Int $J$ Food Microbiol 69, 25-36.

Álvarez-Martín, P., Flórez, A. B., López-Díaz, T. M. \& Mayo, B. (2007). Phenotypic and molecular identification of yeast species associated with Spanish blue-veined Cabrales cheese. Int Dairy J 17, 961-967.

Axelsson, L. (2004). Lactic acid bacteria: classification and metabolism. In Lactic Acid Bacteria: Microbiological and Functional Aspects, 3rd edn, pp. 1-66. Edited by S. Salminen, A. von Wright \& A. C. Ouwehand. New York: Marcel Dekker.

Belloch, C., Villa-Carvajal, M., Álvarez-Rodríguez, M. L. \& Coque, J. J. (2007). Rhodotorula subericola sp. nov., an anamorphic basidiomycetous yeast species isolated from bark of Quercus suber (cork oak). Int J Syst Evol Microbiol 57, 1668-1671.

Beresford, T. P., Fitzsimons, N. A., Brennan, N. L. \& Cogan, T. M. (2001). Recent advances in cheese microbiology. Int Dairy J 11, 259274.

Bockelmann, W. (1999). Secondary cheese cultures. In Technology of Cheesemaking, pp. 132-162. Edited by B. A. Law. London: Sheffield Academic Press.

Esteve-Zarzoso, B., Belloch, C., Uruburu, F. \& Querol, A. (1999), Identification of yeasts by RFLP analysis of the $5.8 \mathrm{~S}$ rRNA gene and the two ribosomal internal transcribed spacers. Int J Syst Bacteriol 49, 329-337.

Ferreira, A. D. \& Viljoen, B. C. (2003). Yeasts as adjunct starters in matured Cheddar cheese. Int J Food Microbiol 86, 131-140.

Flórez, A. B., López-Díaz, T. M., Álvarez-Martín, P. \& Mayo, B. (2006). Microbial characterisation of the traditional Spanish blue-veined Cabrales cheese: identification of dominant lactic acid bacteria. Eur Food Res Technol 223, 503-508.

Gadaga, T. H., Mutukumira, A. N. \& Narvhus, J. A. (2001). The growth and interaction of yeasts and lactic acid bacteria isolated from Zimbabwean naturally fermented milk in UHT milk. Int J Food Microbiol 68, 21-32.

Gripon, J.-C. (1999). Mould-ripened cheeses. In Cheese: Chemistry, Physics and Microbiology, Major Cheese Groups, 2nd edn, vol. 2, pp. 111-136. Edited by P. F. Fox. London: Chapman and Hall.

Kumar, S., Tamura, K. \& Nei, M. (2004). MEGA3: integrated software for molecular evolutionary genetics analysis and sequence alignment. Bioinformatics 5, 150-163.

Kurtzman, C. P. \& Robnett, C. J. (1998). Identification and phylogeny of ascomycetous yeasts from analysis of nuclear large subunit (26S) ribosomal DNA partial sequences. Antonie van Leeuwenhoek 73, 331371.

Kurtzman, C. P. \& Robnett, C. J. (2007). Multigene phylogenetic analysis of the Trichomonascus, Wickerhamiella and Zygoascus yeast clades, and the proposal of Sugiyamaella gen. nov. and 14 new species combinations. FEMS Yeast Res 7, 141-151.

Kurtzman, C. P., Robnett, C. J. \& Basehoar-Powers, E. (2008), Phylogenetic relationships among species of Pichia, Issatchenkia and Williopsis determined from multigene sequence analysis, and the proposal of Barnettozyma gen. nov., Lindnera gen. nov. and Wickerhamomyces gen. nov. FEMS Yeast Res 8, 939-954.

Pitt, J. I. \& Hocking, A. D. (1997). Fungi and Food Spoilage, 2nd edn. London: Blackie Academic \& Professional.

Roostita, R. \& Fleet, G. H. (1996). The occurrence and growth of yeasts in Camembert and blue-veined cheese. Int J Food Microbiol 28, 393-404.

Saitou, N. \& Nei, M. (1987). The neighbour-joining method: a new method for reconstructing phylogenetic trees. Mol Biol Evol 4, 406425.

Wouters, J. T. M., Ayad, E. H. E., Hugenholtz, J. \& Smit, G. (2002). Microbes from raw milk for fermented dairy products. Int Dairy J 12, 91-109.

Yarrow, D. (1998). Methods for the isolation, maintenance and identification of yeasts. In The Yeasts, a Taxonomic Study, 4th edn, pp. 77-100. Edited by C. P. Kurtzman \& J. W. Fell. Amsterdam: Elsevier. 